\title{
Comparison of OneShape, 2Shape and One Curve endodontic instruments for debris and irrigant extrusion
}

\section{Porównanie efektywności usuwania resztek i płynów płuczących z kanałów korzeniowych za pomocą pilników OneShape, 2Shape i One Curve}

\author{
Esma Saricam ${ }^{1, A-D, F}$, Guven Kayaoglu ${ }^{2, A, E, F}$ \\ 1 Department of Endodontics, Faculty of Dentistry, Ankara Yıldırım Beyazıt University, Turkey \\ ${ }^{2}$ Department of Endodontics, Faculty of Dentistry, Gazi University, Ankara, Turkey \\ A - research concept and design; $\mathrm{B}$ - collection and/or assembly of data; $\mathrm{C}$ - data analysis and interpretation; \\ $\mathrm{D}$ - writing the article; $\mathrm{E}$ - critical revision of the article; $\mathrm{F}$ - final approval of the article
}

Address for correspondence

Esma Saricam

E-mail: esaricam@ybu.edu.tr, dt.esmasaricam@gmail.com

Funding sources

None declared

Conflict of interest

None declared

Received on January 12,2020

Reviewed on February 12, 2020

Accepted on March 26, 2020

Published online on September 30, 2020

Cite as

Saricam E, Kayaoglu G. Comparison of OneShape, 2Shape and One Curve endodontic instruments for debris and irrigant extrusion. Dent Med Probl. 2020;57(3):255-259. doi:10.17219/dmp/119771

DOI

$10.17219 / \mathrm{dmp} / 119771$

Copyright

๑) 2020 by Wroclaw Medical University

This is an article distributed under the terms of the

Creative Commons Attribution 3.0 Unported License (CC BY 3.0)

(https://creativecommons.org/licenses/by/3.0/).

\begin{abstract}
Background. Better understanding is needed about the debris-and-irrigant-extrusion potential of the instruments used for root canal preparation procedures, manufactured of different heat-treated alloys.

Objectives. The aim of the study was to evaluate the single-file nickel-titanium (NiTi) rotary system OneShape ${ }^{\circledR}$ and compare it with 2 different heat-treated instrumentation systems produced by the same manufacturer - a single-file C-wire system (One Curve ${ }^{\circledR}$ ) and a multi-file T-wire system $\left(2\right.$ Shape $\left.{ }^{\circledR}\right)$ - in terms of debris and irrigant extrusion.
\end{abstract}

Material and methods. The mesiobuccal root canals of 51 extracted mandibular molar teeth were selected for the study. The roots were applied to the test apparatus prepared with the Myers and Montgomery method. The roots were divided into 3 groups according to the instrumentation system: OneShape; One Curve; and 2Shape. The root canals were prepared according to the manufacturer's instructions. The analysis of variance (ANOVA) and the post hoc Tukey tests were used to evaluate the significance of the amount of the extruded debris and irrigant $(p<0.05)$.

Results. The One Curve group produced less debris extrusion than the 2Shape group $(p<0.05)$. There were no significant differences between the 2Shape and OneShape $(p=0.136)$, or the One Curve and OneShape groups $(p=0.159)$. The weight of the extruded irrigant was significantly lower for the One Curve group as compared to other systems $(p<0.05)$. The mean weight of the extruded irrigant did not differ significantly for the 2Shape and OneShape groups $(p=0.976)$.

Conclusions. The C-wire One Curve system was associated with less apical irrigant extrusion in comparison with the OneShape and 2Shape systems. The amount of debris extrusion produced by the One Curve system was similar to that produced by the OneShape system and lower than in the case of the 2Shape system.

Key words: endodontics, Nitinol, root canal preparation

Słowa kluczowe: endodoncja, Nitinol, przygotowanie kanału korzeniowego 


\section{Introduction}

During root canal preparation procedures, dentine chips, pulpal tissue remnants, irrigation solutions, and microorganisms are often extruded into the periapical region. ${ }^{1}$ This extruded material may cause post-operative pain and flare-ups, and impede apical healing., ${ }^{2,3}$ The amount of the extruded material depends on the size and kinematics of the files and/or the preparation and irrigation techniques applied. ${ }^{4}$

Several improvements in alloys and instrumentation kinematics have revolutionized root canal instrumentation technology in recent years. ${ }^{5}$ However, all instruments and instrumentation techniques have been found to be linked with some amount of material extrusion to the periapical area. ${ }^{6,7}$ Rotary instruments have proven to be associated with a minimized amount of debris extrusion as compared to hand files. ${ }^{4}$ Owing to the development of single-file systems, the multi-step rotary instrumentation system has been simplified to a single step. OneShape ${ }^{\circledR}$ (Micro-Mega SA, Besançon, France) is a single-file nickel-titanium (NiTi) system (tip size 25/.06 taper) that has 3 different cross-sectional designs along the cutting part of the file. ${ }^{8}$ Another single-file system manufactured by Micro-Mega is the One Curve ${ }^{\circledR}$ system (25/.06). This instrument is produced from heat-treated NiTi called C-wire, a shapememory alloy that facilitates root canal preparation with its pre-bending ability. ${ }^{9}$ The One Curve system provides better centering and cutting abilities due to its variable cross-sectional file design ${ }^{10}$ whereas the 2Shape system (Micro-Mega SA) is manufactured with T-wire technology, which provides better cyclic fatigue resistance. ${ }^{11}$ This system contains 2 files - TS1 (25/.04) and TS2 (25/.06). The instruments have an asymmetrical cross-sectional design, comprising a triple helix with 2 main cutting edges and 1 secondary cutting edge for successful debris removal and improved cutting ability. ${ }^{12}$

The OneShape, One Curve and 2Shape systems work in a continuous rotary motion. Previous studies showed that the push-pull instrumentation techniques tended to produce more apical debris extrusion than rotary systems. ${ }^{7,13}$ To date, several studies have examined various rotary systems, ${ }^{8,14}$ or compared the OneShape ${ }^{15-18}$ and 2 Shape files ${ }^{19}$ with other file systems with regard to debris extrusion. However, there are no studies in the available literature evaluating the effects of the systems produced with heat-treating technology on debris and irrigant extrusion. Therefore, the purpose of this study was to compare the OneShape, One Curve and 2Shape systems in terms of debris and irrigant extrusion. The null hypothesis was that there would be no difference among the amount of the extruded debris and irrigant produced with these systems.

\section{Material and methods}

Ethical approval was obtained from the Ethics Committee of Ankara Yıldırım Beyazıt University in Turkey (No. 2019-237). We examined 51 extruded mandibular molar teeth radiographically and visually to confirm the absence of decay, resorption, calcification, open apices, fractures, or cracks. The curvature angle of the mesiobuccal root canals was calculated with Schneider's method, through the digital radiographic images taken from the buccolingual and mesiodistal directions ${ }^{20}$ Root canals having a curvature of up to $5^{\circ}$ were selected for the study. The mesiobuccal roots of the teeth were divided from their crowns at the cementoenamel junction with a high-speed diamond saw under water cooling to set the root length at $16 \mathrm{~mm}$. A size $10 \mathrm{~K}$-file was moved into the root canal until it could be seen at the apical foramen; the working length was determined to be $1 \mathrm{~mm}$ shorter than the root length, i.e., $15 \mathrm{~mm}$. After the working length was achieved with a size $15 \mathrm{~K}$-file, the root canals were randomly allocated into 3 groups: OneShape; One Curve; or 2Shape.

\section{Test apparatus}

The Myers and Montgomery method was used for the test apparatus. ${ }^{21}$ The rubber plugs of glass vials were drilled and the teeth were fixed to those holes with cyanoacrylate. Previously weighed 2-milliliter Eppendorf tubes were inserted into the glass vials. The roots fixed to the plugs were placed in the Eppendorf tubes to save apically extruded material, and two 21-gauge needles were stuck into the rubber plugs to equalize the outside and inside pressure. The Eppendorf tubes were weighed 3 times before being placed in the vials, and the mean weight was determined as the pre-weight. The Eppendorf tubes were weighed on a $10^{-4}$-gram precision balance.

\section{Experimental groups}

The OneShape group $(n=17)$ : The root canals were prepared with the OneShape file $(25 / .06)$ in a continuous rotary motion at a speed of $400 \mathrm{rpm}$ and a torque of $4 \mathrm{~N} / \mathrm{cm}$; the root canals were irrigated with $2 \mathrm{~mL}$ of distilled water after the preparation procedure.

The One Curve group $(n=17)$ : The root canals were prepared with the One Curve file (25/.06) in a continuous rotary motion at a speed of $300 \mathrm{rpm}$ and a torque of $2.5 \mathrm{~N} / \mathrm{cm}$; the root canals were irrigated with $2 \mathrm{~mL}$ of distilled water after the preparation procedure.

The 2Shape Group $(n=17)$ : The root canals were prepared with the TS1 (25/.04) and TS2 (25/.06) files in a continuous rotary motion at a speed of $300 \mathrm{rpm}$ and a torque of $2.5 \mathrm{~N} / \mathrm{cm}$; a total of $2 \mathrm{~mL}$ distilled water $-1 \mathrm{~mL}$ at the instrument change and $1 \mathrm{~mL}$ after the preparation procedure - was used for the irrigation procedure. 
All the instruments were used with an electric torquecontrolled motor (EndoTouch ${ }^{\circledR}$ TC2; SybronEndo, Glendora, USA) in a progressive brushing movement in 3 waves (up-and-down movements) until the apical foramen was reached, according to the manufacturer's instructions. Each file was used to prepare 1 root canal. After the apical foramen was reached, a size $15 \mathrm{~K}$-file was inserted $1 \mathrm{~mm}$ beyond the apical foramen to maintain apical patency before distilled water irrigation. A total of $2 \mathrm{~mL}$ of distilled water was used for each root canal. A 27-gauge openended irrigation needle was inserted to a maximum depth of $1 \mathrm{~mm}$ shorter than the working length and was used with an in-and-out motion for the irrigation procedure.

\section{Evaluation of debris and irrigant extrusion}

After root canal preparation, each Eppendorf tube was removed and immediately weighed 3 times. The mean of these values was taken as final weight-1. All the tubes were incubated at $68^{\circ} \mathrm{C}$ for 5 days to evaporate the extruded irrigant. The tubes were again weighed 3 times and the mean of these measurements was registered as final weight-2. Final weight-2 was subtracted from final weight -1 and recorded as the weight of the extruded irrigant. The pre-weight of the tube was subtracted from final weight- 2 and recorded as the weight of the extruded debris.

\section{Statistical analysis}

The statistical analysis was performed using the IBM SPSS Statistics for Windows software v. 21.0 (IBM Corp., Armonk, USA). Statistical significance was defined at $p<0.05$. The data was examined for the normality of distribution using the Shapiro-Wilk test. The data revealed a normal distribution for the groups. The analysis of variance (ANOVA) and the post hoc Tukey tests were used to evaluate the significance of the amount of the extruded debris and irrigant.

\section{Results}

Table 1 presents the mean $(M)$ and standard deviation $(S D)$ values of debris and irrigant weights for each group. The results showed that there were significant differ- ences between the groups in terms of the extruded debris $(p=0.002)$ and irrigant weights $(p=0.007)$. The One Curve group produced less debris extrusion as compared to the 2Shape group $(p=0.001)$, but there was no significant difference between the 2Shape and OneShape $(p=0.136)$, or the One Curve and OneShape groups $(p=0.159)$. As far as irrigant extrusion is concerned, the One Curve group produced a lower irrigant extrusion weight as compared to the 2Shape $(p=0.022)$ or OneShape groups ( $p=0.013)$. The mean weight of the extruded irrigant did not differ significantly for the 2Shape and OneShape groups $(p=0.976)$.

\section{Discussion}

This study compared the apically extruded debris and irrigant produced with the OneShape, One Curve and 2Shape instrumentation systems. All the instrumentation systems were operated in a continuous rotation motion. The OneShape and One Curve systems are single-file systems whereas the 2Shape system is a multi-file system. The amount of the extruded debris produced with One Curve was lower than the amount produced with 2Shape, but similar to the amount produced with OneShape. The weight of the extruded irrrigant was lower for the One Curve group as compared to other systems. Thus, the null hypothesis of the study was rejected.

All the file systems used in the study created some amount of debris and irrigant. The systems were operated with rotational movements, which tend to move tissue remnants toward the root canal orifice. ${ }^{22}$ All the systems used in the study provided similar final apical sizes and tapers in the root canals. Variability in the amount of the extruded material produced by the 3 systems could be related to differences in the file design and alloy materials. The OneShape system is produced from NiTi whereas the other 2 systems are manufactured from different heat-treated NiTi alloys. The cutting part of the OneShape file has 3 different cross-sectional designs. ${ }^{23}$ In the apical part, 3 cutting edges are present whereas the middle part has either 2 or 3 cutting edges. In the coronal third, there are $2 \mathrm{~S}$-shaped cutting edges. The One Curve system files are produced with $\mathrm{C}$-wire technology, which provides shape memory. Its alloy is obtained through electropolishing and heat-treatment procedures.

Table 1. Weights of the extruded debris and irrigant for each group

\begin{tabular}{|c|c|c|c|c|c|c|}
\hline \multirow{2}{*}{ Group } & \multicolumn{3}{|c|}{ Debris [g] } & \multicolumn{3}{|c|}{ Irrigant [g] } \\
\hline & $M \pm S D$ & F-value & $p$-value & $M \pm S D$ & F-value & $p$-value \\
\hline OneShape & $0.00058 \pm 0.00020^{a, b}$ & & & $1.19014 \pm 0.40538^{\mathrm{a}}$ & & \\
\hline One Curve & $0.00044 \pm 0.00013^{a}$ & 7.300 & $0.002^{*}$ & $0.84802 \pm 0.26694^{b}$ & 5.502 & $0.007^{*}$ \\
\hline 2Shape & $0.00072 \pm 0.00028^{b}$ & & & $1.16596 \pm 0.31980^{\mathrm{a}}$ & & \\
\hline
\end{tabular}

$M$ - mean; SD - standard deviation; * statistical significance (ANOVA; normally distributed data). Different lower-case letters indicate significant differences between the groups in either debris or irrigant weights $(p<0.05)$. 
The 4-millimeter apical part of the One Curve file has a triple-helix cross-sectional design and the rest of the file is designed with an S-shaped cross-section with 2 blades. ${ }^{24}$ The 2 Shape system consists of 2 files manufactured with T-wire technology. A triple-helix crosssectional design beyond the shaft of the 2Shape file allows better adaptation to the root canal walls. ${ }^{25}$

The triple-helix cross-sectional design of the 2Shape file underlies the entire cutting part of the file, while only the apical part of the One Curve file has this design. This difference may bring the 2 Shape system into a tighter contact with the root canals, thus improving the shaping ability. ${ }^{25}$ However, a tight contact may also block the produced debris from being removed through the root canal opening. More instrument usage was associated with more debris production. ${ }^{26}$ The 2 Shape system is the only multi-file system we tested and its mean debris extrusion value was the highest among the groups. The amount of debris extrusion for the OneShape and One Curve groups was similar. The configuration of the One Curve system was developed as a modified form of the OneShape system. ${ }^{24}$ Their design similarity may affect the removal of debris in a similar direction.

A total of $2 \mathrm{~mL}$ distilled water was used for the irrigation procedure in all 3 groups. In the OneShape and One Curve groups, irrigation was performed at the end of the preparation procedure, since these 2 systems are singlefile systems. The 2 Shape system consists of 2 files, so the irrigation procedure was applied in 2 stages, with $1 \mathrm{~mL}$ of distilled water for each stage. The One Curve system produced a lower amount of irrigant extrusion as compared to the OneShape and 2Shape systems.

Sodium hypochlorite $(\mathrm{NaOCl})$ is a widely accepted irrigation solution due to its excellent antimicrobial activity. However, in this study, distilled water was used as the irrigation solution, although it is not generally preferred as the main irrigant. Sodium hypochlorite has been reported to increase the weight of the extruded debris by producing particulate precipitates, thus compromising the reliability of measurements. ${ }^{27}$

A commonly applied experimental model, which was described by Myers and Montgomery, was used for saving the debris and irrigant collection. ${ }^{21}$ This system does not simulate clinical conditions, since it does not mimic periradicular tissues. Other recommended models, such as floral foam or agarose gel models, are reported to provide resistance around the apical foremen and to mimic periapical back pressure..$^{28,29}$ Moreover, these systems give the total value of debris and irrigant weights, and the wide surface area of floral foam lets the irrigant evaporate immediately and may lead to incorrect results. The Myers and Montgomery method, on the other hand, offers the opportunity to individually evaluate debris and irrigant weights.

The OneShape system is produced from the NiTi alloy, which provides the file with superelasticity, shape memory and ease in canal preparation. ${ }^{30}$ Various kinds of thermomechanical treatment of NiTi developed the structure and transformation performance of file systems. ${ }^{31,32}$ The OneShape, One Curve and 2Shape systems are produced by the same manufacturer with different designs and heat-treated alloys. The One Curve system, produced with $\mathrm{C}$-wire technology, was introduced most recently, and this system provided lower debris and irrigant extrusion than the other ones.

\section{Conclusions}

The One Curve system exhibited lower amounts of debris and irrigant in comparison with the 2Shape system. The debris extrusion produced by the OneShape and 2Shape systems was similar.

\section{ORCID iDs}

Esma Saricam (1) https://orcid.org/0000-0001-7701-4214

Guven Kayaoglu (ib https://orcid.org/0000-0002-6562-6034

\section{References}

1. Farmakis ETR, Sotiropoulos GG, Abramovitz I, Solomonov M. Apical debris extrusion associated with oval shaped canals: A comparative study of WaveOne vs Self-Adjusting File. Clin Oral Investig. 2016;20(8):2131-2138.

2. Seltzer S, Naidorf IJ. Flare-ups in endodontics: I. Etiological factors. J Endod. 1985;11(11):472-478.

3. Siqueira JF, Jr. Microbial causes of endodontic flare-ups. Int Endod J. 2003;36(7):453-463.

4. Kuştarci A, Akpinar KE, Er K. Apical extrusion of intracanal debris and irrigant following use of various instrumentation techniques. Oral Surg Oral Med Oral Pathol Oral Radiol Endod. 2008;105(2):257-262.

5. Mendonça de Moura JD, da Silveira Bueno CE, Fontana CE, Pelegrine RA. Extrusion of debris from curved root canals instrumented up to different working lengths using different reciprocating systems. J Endod. 2019;45(7):930-934.

6. Kherlakian D, Cunha RS, Ehrhardt IC, Zuolo ML, Kishen A, da Silveira Bueno CE. Comparison of the incidence of postoperative pain after using 2 reciprocating systems and a continuous rotary system: A prospective randomized clinical trial. J Endod. 2016;42(2):171-176.

7. Bürklein S, Schäfer E. Apically extruded debris with reciprocating single-file and full-sequence rotary instrumentation systems. J Endod. 2012;38(6):850-852.

8. Mittal R, Singla MG, Garg A, Dhawan A. A comparison of apical bacterial extrusion in manual, ProTaper rotary, and One Shape rotary instrumentation techniques. J Endod. 2015;41(12):2040-2044.

9. Topçuoğlu HS, Topçuoğlu G, Kafdağ O, Balkaya H. Effect of two different temperatures on resistance to cyclic fatigue of One Curve, EdgeFile, HyFlex CM and ProTaper Next files. Aust Endod J. 2020;46(1):68-72 (Epub 2019).

10. Elnaghy AM, Elsaka SE. Cyclic fatigue resistance of One Curve, 2Shape, ProFile Vortex, Vortex Blue, and RaCe nickel-titanium rotary instruments in single and double curvature canals. J Endod. 2018;44(11):1725-1730.

11. Uslu G, Özyürek T, Gündoğar M, Yılmaz K. Cyclic fatigue resistance of 2Shape, Twisted File and EndoSequence Xpress nickel-titanium rotary files at intracanal temperature. J Dent Res Dent Clin Dent Prospects. 2018;12(4):283-287.

12. Singh S, Mirdha N, Shilpa PH, Tiwari RVC, Abdul MSM, Sainudeen S. Shaping ability of 2Shape and WaveOne Gold files using conebeam computed tomography. J Int Soc Prev Community Dent. 2019;9(3):245-249.

13. Sen OG, Bilgin B, Koçak S, Sağlam BC, Koçak MM. Evaluation of apically extruded debris using continuous rotation, reciprocation, or adaptive motion. Braz Dent J. 2018;29(3):245-248. 
14. Koçak MM, Çiçek E, Koçak S, Sağlam BC, Yılmaz N. Apical extrusion of debris using ProTaper Universal and ProTaper Next rotary systems. Int Endod J. 2015;48(3):283-286.

15. Pawar AM, Pawar M, Kfir A, Thakur B, Mutha P, Banga KS. Effect of glide path preparation on apical extrusion of debris in root canals instrumented with three single-file systems: An ex vivo comparative study. J Conserv Dent. 2017;20(2):110-114.

16. Topçuoğlu HS, Düzgün S, Akpek F, Topçuoğlu G, Aktı A. Influence of a glide path on apical extrusion of debris during canal preparation using single-file systems in curved canals. Int Endod $J$. 2016;49(6):599-603.

17. Ehsani M, Farhang R, Harandi A, Tavanafar S, Raoof M, Galledar S. Comparison of apical extrusion of debris by using single-file, full-sequence rotary and reciprocating systems. J Dent (Tehran). 2016;13(6):394-399.

18. Bürklein S, Benten S, Schäfer E. Quantitative evaluation of apically extruded debris with different single-file systems: Reciproc, F360 and OneShape versus Mtwo. Int Endod J. 2014;47(5):405-409.

19. Ghoneim WM, Shaheen NA. Apically extruded debris associated with different instrumentation systems and irrigation needles. Tanta Dent J. 2018;15(2):105-110.

20. Schneider SW. A comparison of canal preparations in straight and curved root canals. Oral Surg Oral Med Oral Pathol. 1971;32(2):271-275.

21. Myers GL, Montgomery S. A comparison of weights of debris extruded apically by conventional filing and Canal Master techniques. J Endod. 1991;17(6):275-279.

22. Ferraz CC, Gomes NV, Gomes BP, Zaia AA, Teixeira FB, Souza-Filho FJ. Apical extrusion of debris and irrigants using two hand and three engine-driven instrumentation techniques. Int Endod $\mathrm{J}$. 2001;34(5):354-358.

23. Gündoğar M, Özyürek T. Cyclic fatigue resistance of OneShape HyFlex EDM, WaveOne Gold, and Reciproc Blue nickel-titanium instruments. J Endod. 2017;43(7):1192-1196.

24. Staffoli S, Grande NM, Plotino G, et al. Influence of environmental temperature, heat-treatment and design on the cyclic fatigue resistance of three generations of a single-file nickel-titanium rotary instrument. Odontology. 2019;107(3):301-307.

25. Kaloustian MK, Nehme W, El Hachem C, et al. Evaluation of two shaping systems and two ultrasonic irrigation devices in removing root canal filling material from mesial roots of mandibular molars: A micro CT study. Dent J (Basel). 2019;7(1):2.

26. Kirchhoff AL, Fariniuk LF, Mello I. Apical extrusion of debris in flatoval root canals after using different instrumentation systems. J Endod. 2015;41(2):237-241.

27. Tanalp J, Güngör T. Apical extrusion of debris: A literature review of an inherent occurrence during root canal treatment. Int Endod J. 2014;47(3):211-221.

28. Altundasar E, Nagas E, Uyanik O, Serper A. Debris and irrigant extrusion potential of 2 rotary systems and irrigation needles. Oral Surg Oral Med Oral Pathol Oral Radiol Endod. 2011;112(4):e31-e35.

29. Lu Y, Wang R, Zhang $L$, et al. Apically extruded debris and irrigant with two Ni-Ti systems and hand files when removing root fillings: A laboratory study. Int Endod J. 2013;46(12):1125-1130.

30. Walia HM, Brantley WA, Gerstein H. An initial investigation of the bending and torsional properties of Nitinol root canal files. J Endod. 1988;14(7):346-351.

31. Goo HJ, Kwak SW, Ha JH, Pedullà E, Kim HC. Mechanical properties of various heat-treated nickel-titanium rotary instruments. J Endod. 2017;43(11):1872-1877.

32. Zhao D, Shen Y, Peng B, Haapasalo M. Effect of autoclave sterilization on the cyclic fatigue resistance of thermally treated nickeltitanium instruments. Int Endod J. 2016;49(10):990-995. 
